\title{
Erratum to: Sentinel Lymph Node Biopsy in Multicentric Breast Cancer: Five-Year Results in a Large Series from a Single Institution
}

Oreste Gentilini, $\mathrm{MD}^{\mathbf{1}}$, Paolo Veronesi, $\mathrm{MD}^{1,2}$, Edoardo Botteri, $\mathrm{MSc}^{3}$, Fiammetta Soggiu, $\mathrm{MD}^{1}$, Giuseppe Trifirò, $\mathrm{MD}^{4}$, Germana Lissidini, $\mathrm{MD}^{1}$, Viviana Galimberti, $\mathrm{MD}^{1}$, Simona Musmeci, $\mathbf{M S c}^{1}$, Paola Rafaniello Raviele, $\mathrm{MD}^{5}$, Antonio Toesca, $\mathrm{MD}^{1}$, Silvia Ratini, $\mathrm{MD}^{1}$, Andres Del Castillo, MD ${ }^{1}$, Marco Colleoni, $\mathrm{MD}^{6}$, Nina Talakhadze, $\mathrm{MD}^{1}$, Nicole Rotmensz, $\mathrm{MSc}^{3}$, Giuseppe Viale, $\mathrm{MD}^{2,5}$, Umberto Veronesi, $\mathrm{MD}^{1}$, and Alberto Luini, $\mathrm{MD}^{1}$

${ }^{1}$ Division of Senology, European Institute of Oncology, Milano, Italy; ${ }^{2}$ University of Milan School of Medicine, European Institute of Oncology, Milano, Italy; ${ }^{3}$ Division of Epidemiology and Biostatistics, European Institute of Oncology, Milano, Italy; ${ }^{4}$ Nuclear Medicine Department, European Institute of Oncology, Milano, Italy; ${ }^{5}$ Department of Pathology and Laboratory Medicine, European Institute of Oncology, Milano, Italy; ${ }^{6}$ Department of Medical Oncology, European Institute of Oncology, Milano, Italy

\section{ERRATUM TO: ANN SURG ONCOL} DOI 10.1245/S10434-011-1694-3

In article, "Sentinel Lymph Node Biopsy in Multicentric Breast Cancer: Five-Year Results in a Large Series from a Single Institution,” (10.1245/s10434-011-1694-3), author Andres Del Castillo's name was misspelled. The correct authorship for this article is:

Gentilini O, Veronesi P, Botteri E, Soggiu F, Trifirò G, Lissidini G, Galimberti V, Musmeci S, Raviele PR, Toesca A, Ratini S, Del Castillo A, Colleoni M, Talakhadze N, Rotmensz N, Viale G, Veronesi U, Luini A.

The online version of the original article can be found under doi:10.1245/s10434-011-1694-3.

(C) Society of Surgical Oncology 2011

Published Online: 11 May 2011

O. Gentilini, MD

e-mail: oreste.gentilini@ieo.it 